\title{
Local History Practice in the System of Bachelors-Historians Training: Experience and Prospects
}

\author{
Olga Vovk ${ }^{1, *} \&$ Sergiy Kudelko ${ }^{2}$ \\ ${ }^{1}$ Academician P. T. Tronko Center for Area Studies, V. N. Karazin Kharkiv National University, Kharkiv, Ukraine \\ ${ }^{2}$ Department of Historiography, Source Studies, and Archaeology, School of History, V. N. Karazin Kharkiv \\ National University, Kharkiv, Ukraine \\ *Correspondence: V. N. Karazin Kharkiv National University, 4 Svobody Sq., Kharkiv, 61022, Ukraine. E-mail: \\ tronkocentr@karazin.ua
}

Received: December 7, 2021

Accepted: January 6, 2022 Online Published: January 17, 2022

doi:10.5430/jct.v11n1p129

URL: https://doi.org/10.5430/jct.v11n1p129

\begin{abstract}
The article describes and summarizes the experience of conducting local history educational and productive practice for students of the first (bachelor's) level of education, majoring in "History and Archeology" at the School of History, V.N.Karazin Kharkiv National University (Ukraine). The authors show that the set of principles and research methods, being the basis of this investigation, ensures reliability of the analysis and representativeness of the results. A review of the latest publications on the topic confirmes its relevance and lack of development in the specialized literature. The article substantiates the important role and significance of the local history educational and productive practice for further professional activity of the future graduates. The authors explain the main approaches to the organization of this form of educational activity in traditional conditions (among such approaches - the implementation of creative projects in small groups, excursions and expeditions). The article reveals the changes that took place in the process of organizing and conducting local history educational and productive practice after the outbreak of the coronary crisis. The approaches and methods, developed for the distance passing of local history educational and productive practice, may be useful after returning to the traditional system of education. The authors, using a correlation-regression analysis of the ratio of the number of students who underwent local history educational and productive practice and the number of students - speakers at the International Local History Conference of Young Scientists, found a moderate correlation between these indicators. The article concludes that the local history educational and productive practice encourages students to further research activity in the field of local history.
\end{abstract}

Keywords: university education, local history, practical training of students, educational and productive practice, distance learning

\section{Introduction}

The main purpose of higher education is to train a highly qualified specialist, who has not only mastered the theoretical foundations of the chosen specialty, but also is able to put his knowledge into practice. However, modern Ukrainian universities do not always pay due attention to the methodological problems of productive practice organization. This problem was especially exacerbated with the outbreak of the COVID-19 pandemic, during which all participants in the learning process were forced to respond urgently to the challenges of time and find new tools for interaction.

This article summarizes the experience of local history educational and productive practice for students majoring in "History and Archeology" at Bachelor's level at V. N. Karazin Kharkiv National University (V. N. Karazin KhNU, Ukraine) and shows the importance of this form of educational activity in acquiring professional competencies by the students.

The aim of the article is to cover the historical dynamics of methods and forms of local history practice organization, to analyze the results achieved by the students in the context of training a highly qualified specialist capable of independent creative and research activities.

Objectives of the article are: 
- to show the role and importance of local history practice in the system of bachelor-historian training;

- to describe the main approaches to the organization of practice and its results in traditional conditions and in the quarantine through COVID-19;

- to demonstrate the role of local history educational and productive practice as an important factor, encouraging students to further develop educational projects and do research in the field of local history.

The research hypothesis is that students who have undergone local history educational and productive practice further demonstrate a growing interest in research activities in the field of local history.

\section{Literature Review}

A number of scientific publications highlight practical training of students of history. Thus, the literature discussed the impact of the university educational environment on the disciplinary training practices of future specialists in the field of history, formation of students' experience and their mastery of practical skills and activities (Anderson \& Day, 2005). Some literary sources also describe the impact of practical work on the territory of historical places, in archives, libraries and museums on further professional teaching activity (Coddington, 2020). Much attention is paid to the activity of employees of archival and museum institutions as mentors for students and practicing teachers, revealing the prospects of cooperation between these groups of participants in the pedagogical process (Patterson, 2020). A series of articles describe specific examples of collaboration between universities and national archives (Maughan \& Jane, 2020) and museums (Schuster \& Grainger, 2021) in the field of training future professionals and creating a collaborative creative product.

The publications also consider some aspects of modern education, which directly affect the organization of local history practice. In particular, there is an emphasis on the prospects of interdisciplinary interaction in the teaching of general and special courses (Bowcutt \& Caulkins, 2020). Some sources emphasize the role of historical, natural and other museums as special places of pedagogical meetings, interdisciplinary platforms, which are of great value for development of educational theories. (Clark et al., 2016).

Researchers have pointed out the importance of students' work with historical sources (including manuscripts and ancient books), which stimulates the development of cognitive activity (Homrighausen, 2020). In addition, they show the results of digitized documentary sources use in the classroom, as well as the significance and benefits of such an approach in the process of history students' training (Guerrero Elecalde, 2020).

Some authors touched upon the importance of tourist travel as a means of learning about the surrounding reality and historical past, their role in the process of human capital formation, as well as the specifics of tourism and education interaction (Fedorchenko et al., 2021). The authors analyzed the results of using mobile services - accumulators of information about historical monuments of the region during the university courses in history and monuments (Varfolomeyev et al., 2015a) and in the field of historical tourism (Varfolomeyev et al., 2015b).

Some papers actively discussed various aspects of digital technologies' application in the educational process. For example, they paid attention to the key principles of building effective digital educational platforms. Digitalization is an effective tool, forming a creative learning environment (Fadeev, 2019). Some literary sources paid particular attention to this problem with the spread of coronavirus and introduction of quarantine restrictions. Thus, the authors studied the objective and subjective problems, faced by teachers and students, who were forced to urgently switch to new models of interaction (Sushko \& Pronchev, 2021). At the same time, the current challenges and trends in the field of education digitalization were correlated with the socio-perceptual characteristics of the "Generation Z" representatives. Today, they make up the dominant majority among all higher education seekers (Bilotserkovets et al., 2021).

Moreover, some aspects of the problem, raised in the article, have already been discussed in modern scientific publications. However, a number of important methodological aspects of specialized local history educational and productive practice, its importance as a tool to intensify research activities of students of history have not yet found their full coverage.

\section{Research Methodology}

The authors used principles of historicism, systematization, and interdisciplinarity to achieve the set goal and solve problems. Adherence to these principles was achieved by using a set of general scientific, special-historical and interdisciplinary methods. 
The article specifies the following among the special-historical methods. The historical-genetic method allowed the authors to trace successive stages in the development of local history educational and productive practice in the system of the bachelor-historians education. Applying the historical-comparative method, the authors have analyzed the changes in approaches to practice after the introduction of quarantine restrictions associated with the COVID-19 pandemic. The historical-typological method analyzed the types of tasks performed by trainees, tracking changes in their topics.

The methods of mathematical statistics, used to test the hypothesis formulated in the article, allowed us to implement the principle of interdisciplinarity. The article examines student groups of the School of History of V.N. Karazin KhNU, whose summer local history educational and productive practice took place during 2013-2021 (a total of 284 people). In addition, we studied the student groups which participated in the International Local History Conference of Young Scientists in 2013-2020 (in general) 203 persons) to determine the impact of local history educational and productive practice on the cognitive research activity of former trainees. Applying the correlation-regression analysis, the authors showed interdependence of these two indicators. In particular, Pearson's correlation criterion rxy was used to establish the existence of a linear relationship between two quantitative indicators. Student's t-test was used to compare the two quantitative samples according to the average values, assessing statistical reliability of the obtained data. The calculations were performed using Microsoft Excel for Windows.

The authors used tabular, graphical and cartographic methods of presenting information in the research, which made it possible to visualize the obtained data.

Thus, the applied principles and methods of research allowed the authors to achieve the goals and objectives set, ensured the reliability of the analysis and representative results.

\section{Results}

Local history educational and productive practice for students-historians was held for the first time at V.N. Karazin Kharkiv National University (V.N. Karazin KhNU) in 2013. It takes place under the scientific and methodological guidance of the Department of Historiography, Source Studies and Archeology of the School of History. The practice base is Academician P. T. Tronko Center for Area Studies.

The purpose of the practice is to form and develop students' professional competencies, master modern methods and approaches of historical and local history research, types of work organization, as well as to improve skills in working with libraries, museums, archives funds.

Local history practice is designed for 3rd year students of the first (bachelor's) level of higher education, majoring in "History and Archeology", full-time education. The practice lasts three weeks and is held after the spring semester of the third year of study. Its theoretical basis is lecture courses, attended by the students during the semester, including the basics of local history, historical geography, museum studies, historical anthropology, history of Ukraine and other related disciplines. It is also important that during this practice students have the opportunity to consolidate and improve the skills acquired in the process of archaeological (after 1 year) and museum-archival (after 2 years) productive practices (Pavlova \& Kudelko, 2015).

In the first years of its existence, local history practice at V.N .Karazin KhNU had a variable status and was an alternative to pedagogical practice. It has been mandatory since 2020. This was facilitated, on the one hand, by the successful local history practice in previous years and, on the other hand, by the quarantine conditions caused by the COVID-19 pandemic, which made it impossible to conduct pedagogical practice on the basis of children's summer health camps. Higher status of local history practice has affected the number of trainees. For example, in 2013 there were 17 people, in 2014 - 16, in 2015 - 25, in 2016 - 21, in 2017 - 17, in 2018 - 20, in $2019-41$. In 2020, there were 61 students, in $2021-66$ students (see Figure 1). 


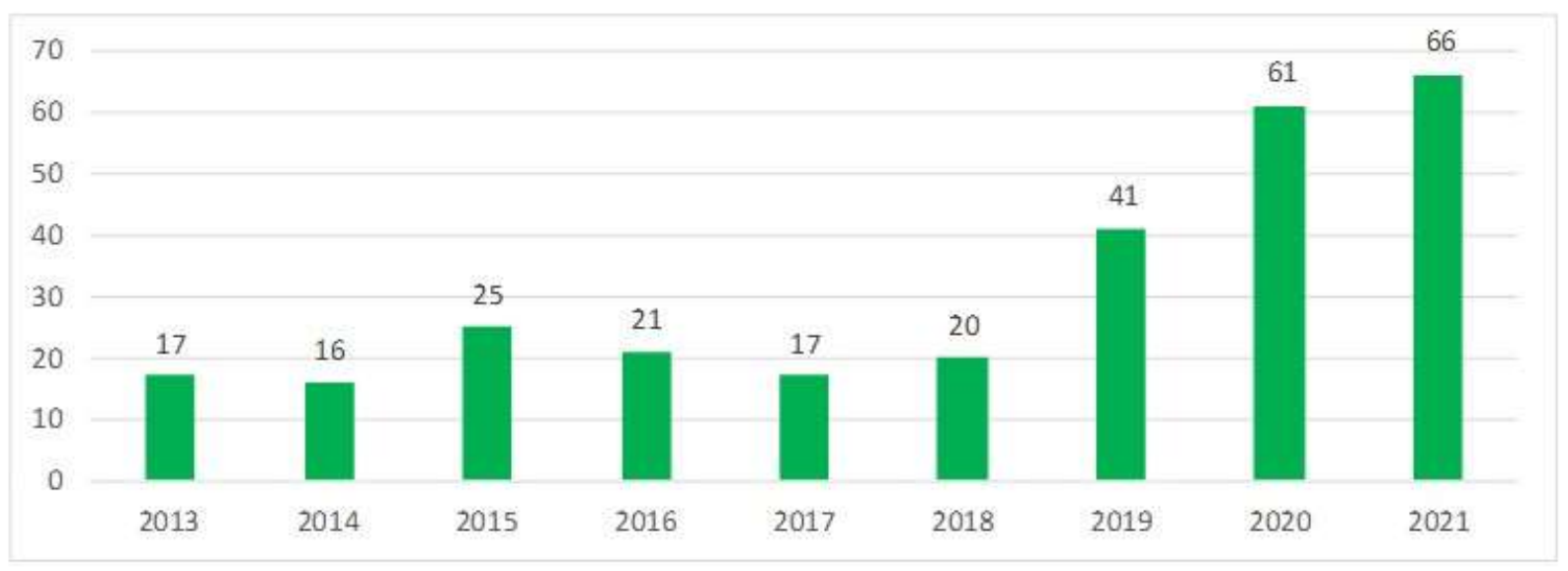

Figure 1. Dynamics of the Number of Students, Taking Part in the Local History Educational and Productive Practice in 2013-2021

The first stage of local history educational and productive practice is to theoretically prepare the students to choose the topic of the project they will develop. According to the lesson plan developed by the heads of practice and specialists from basic institutions, the students attend classes, and this deepens their knowledge in the chosen direction of local history research. Such classes are organized directly on the premises of the Academician P. T. Tronko Center for Area Studies, V. N. Karazin KhNU, in museums, on the streets and historical sites of Kharkiv and the region. In this case, resources of distance learning systems can also be used to organize classes.

Excursions and expeditions corresponding to the theme of the conducted theoretical classes contribute to the deepening and mastering of the theoretical course. During such field trips, students have the opportunity to visually explore the sights of the region, to get acquainted with the methodological foundations of the tour. Thus, before the COVID-19 pandemic and the introduction of related quarantine restrictions for trainees, we organized excursions and expeditions in Kharkiv region and adjacent regions - Sumy, Poltava and Dnipropetrovsk (see Figure 2).

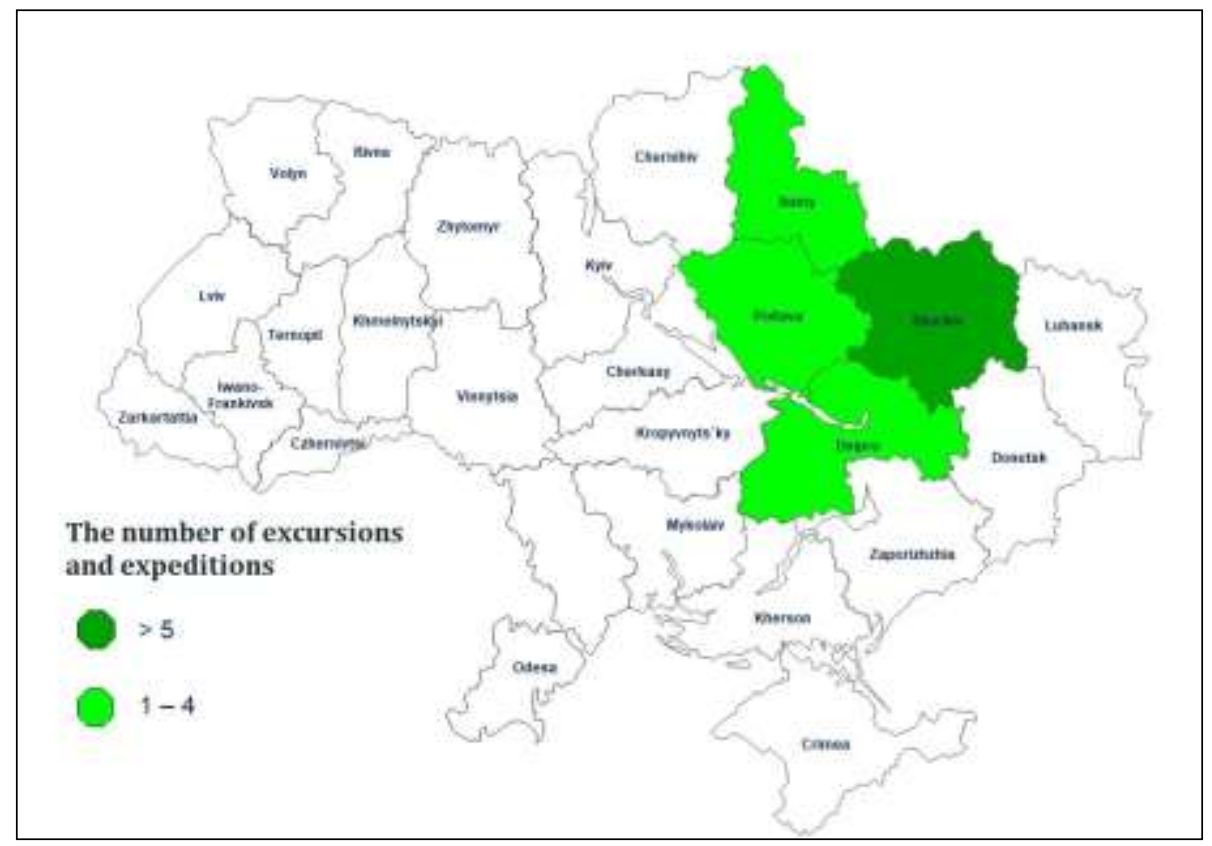

Figure 2. Geography of Excursions and Expeditions of the Participants of Local History Educational and Productive Practice in 2013-2019. 
Visits to local history museums, historical and industrial museums, art museums and galleries, as well as to protected areas, were organized as part of the excursions (see Table 1).

Table 1. Cultural Institutions and Protected Areas Visited During the Local History Educational and Productive Practice in 2013-2019

\begin{tabular}{|c|c|c|}
\hline $\begin{array}{c}\text { Types of } \\
\text { establishments }\end{array}$ & Visited establishments & Regions \\
\hline $\begin{array}{l}\text { Local history } \\
\text { museums }\end{array}$ & $\begin{array}{ll}\text { - } & \text { Dvorichna Museum of Local History } \\
\text { - } & \text { P. D. Martynovych Krasnograd Museum of Local History } \\
\text { - } & \text { Chuguiv Museum of Local History } \\
\text { - } & \text { Vasyl Krychevsky Poltava Museum of Local History } \\
\text { - } & \text { Sumy Regional Museum of Local History } \\
\text { - } & \text { Okhtyrka City Museum of Local History } \\
\text { - } & \text { Trostyanets District Museum of Local History }\end{array}$ & $\begin{array}{l}\text { Poltava region } \\
\text { Sumy region }\end{array}$ \\
\hline $\begin{array}{l}\text { Historical museums } \\
\text { and reserves }\end{array}$ & 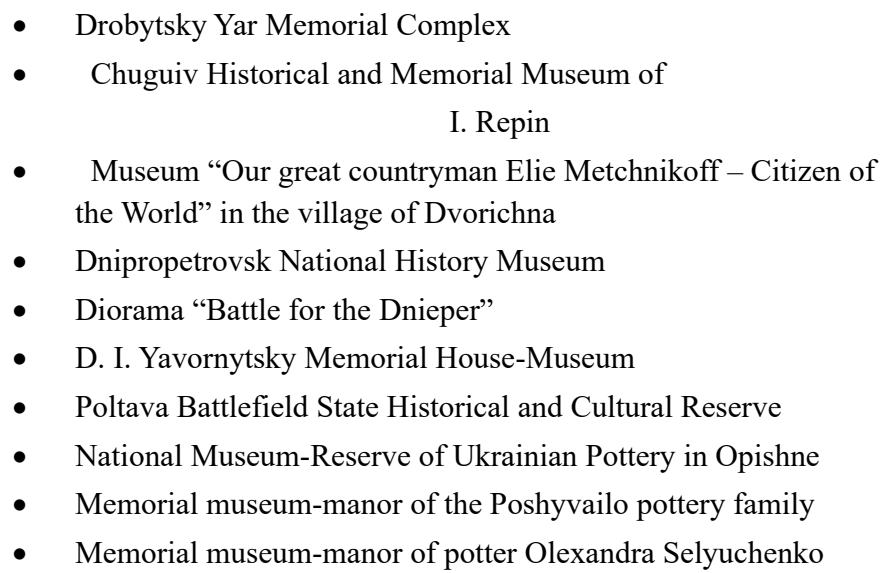 & Dnipropetrovsk region \\
\hline $\begin{array}{l}\text { Art museums and } \\
\text { galleries }\end{array}$ & $\begin{array}{ll}\text { - } & \text { P.F. Lunev Parkhomivka Historical and Art Museum } \\
\text { - } & \text { Chuguiv Art Gallery } \\
\text { - } & \text { Nikanor Onatsky Sumy Regional Art Museum } \\
\text { - } & \text { B. K. Rudnev Lebedyn City Art Museum }\end{array}$ & $\begin{array}{l}\text { Kharkiv region } \\
\text { Sumy region }\end{array}$ \\
\hline $\begin{array}{l}\text { Industrial and } \\
\text { departmental } \\
\text { museums }\end{array}$ & $\begin{array}{l}\text { - } \quad \text { Museum of faience in the village of Buda } \\
\text { - } \quad \text { Museum of water in the village of Kochetok } \\
\text { - } \quad \text { Chocolate Museum in the town of Trostianets }\end{array}$ & Kharkiv region \\
\hline $\begin{array}{l}\text { National natural } \\
\text { parks }\end{array}$ & $\begin{array}{l}\text { - } \text { Gomilshansky Forests National Park } \\
\text { - Dvorichansky National Park }\end{array}$ & Kharkiv region \\
\hline
\end{tabular}

After the outbreak of the COVID-19 pandemic and introduction of quarantine restrictions in 2019/2020 and 2020/2021 academic years, local history educational and productive practice was conducted remotely. This facilitated field trips and excursions. During this period, the main platform for interaction between managers and interns was a distance course on the Moodle platform. It contained the following main elements:

- information about the course (title page, annotation, purpose and tasks, structure and scenario of practice, assessment system, methodical recommendations for studying the course);

- tools for communication with students (forum, chat);

- instructions on occupational and life safety;

- trainee survey;

- lecture materials and tasks for self-examination;

- scientific reference apparatus (list of basic and auxiliary literature, list of useful web links, glossary); 
- forms for downloading completed projects;

- samples of reporting documents and requirements to them;

- feedback forms for messages, suggestions and wishes.

As a supplement to the Moodle toolkit, we have been using IP-telephony to communicate with the students.

The texts of eight lectures were offered to the attention of trainees, in which the teachers stated the main theoretical provisions of local history, covering the main aspects of natural, geographical, art, literary, ecclesiastical, tourist local history, local history biography. Each lecture was accompanied by questions and tasks for self-examination, as well as links to monographs, reference books and scientific articles on the topic, web pages of relevant institutions, sites of research and popular science projects.

In the second week of the educational and productive practice, there was a colloquium conducted by means of video communication. The issues of theory, history and the current state of development of local history were discussed during it. Students reflected on the path of historical development of this discipline, analyzed the common and distinctive features of scientific (academic) and amateur (mass) local history, expressed their views on the relationship between local history, historical regionalism and microhistory (Vovk \& Kudelko, 2020).

The students had an opportunity to consolidate the acquired theoretical knowledge and improve their practical skills of exploratory local history work while writing essays. Each student received an individual topic with a brief description of the native land in terms of history, source studies, biography, archeology, ethnology, science, toponymy, architecture, etc. The object of a local history description could be either the native settlement, district, region, or the city of Kharkiv, where they are studying at the university. As there were a large number of proposed topics and the wide geographical coverage of the student body at the School of History of V. N. Karazin KhNU (see Figure 3), the topics of the essay were not repeated and each of them turned out to be truly individual.

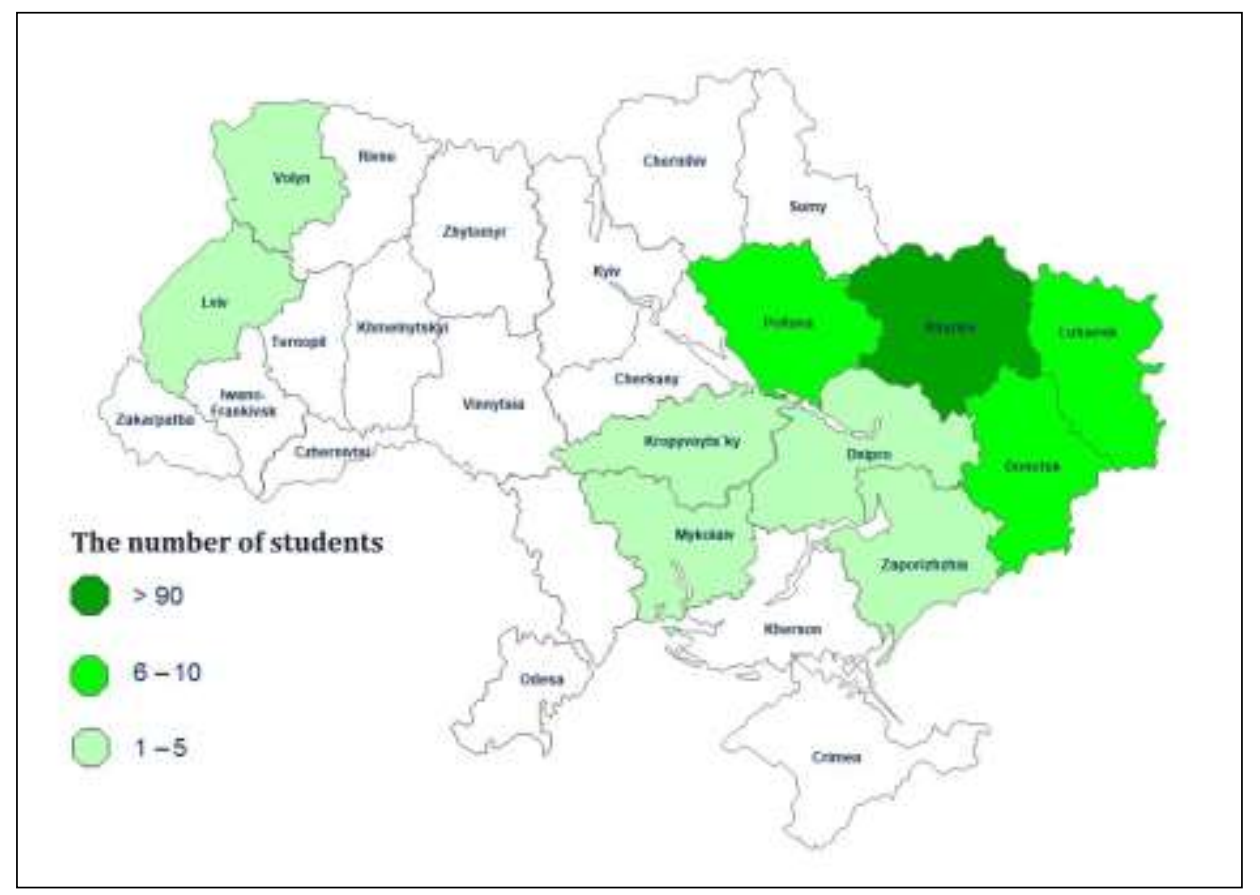

Figure 3. Geography of the Actual Location of Students During the Distance Local History Practice in 2020-2021

The practice program stipulates that students use the knowledge gained during lectures and field trips to do creative or research projects. The trainees are split into subgroups (2-4 people, depending on the complexity of the topic and task), each of which working on a separate project. Optionally, the student can develop the selected topic individually. They select the projects, considering scientific interests and their interests, the topics of their qualification work, also depending on current research topics and practical tasks of the departments.

To carry out individual creative or research projects, a group of trainees was split into subgroups. At the same time, the managers ruled out stochastic methods of segmentation. In 2013-2019, when the practice was off-line, we used 
the survey method. After the introduction of the quarantine regime in connection with the COVID-19 pandemic, when the practice became on-line, a questionnaire method was used for this purpose. In particular, trainees gave the following information about themselves:

- actual location at the time of the practice;

- contacts;

- a field of scientific interests;

- $\quad$ areas of activity and skills that the student considers a priority and wants to develop them during the practice (photography, graphic design, development of tourist routes, typing of handwritten and printed texts, creation and filling of databases, creation of bibliographies, shooting and editing videos, translation texts in foreign languages, etc.).

The obtained data allowed us to find an individual approach to each concrete student. Note that, students had the opportunity to determine the personal composition of subgroups. This allowed to maintain a favorable psychological climate in micro-teams. Consequently, it was possible to achieve optimal results of project implementation.

Table. 2 shows the scope of projects completed by the trainees.

Upon completion of the practice, students submit project reporting materials together with a completed diary and practice report to the supervisors. In particular, the report should reflect the following items:

- the beginning and the end of practice;

- description of field trips, list of museums, reserves, etc., visited during the trips, description of the exhibits;

- characteristics of the individual project, its purpose and main content;

- the list of library, museum, archival institutions, the funds processed during the task;

- brief analysis of the processed literature and online materials;

- presentation of collected and systematized data;

- conclusions.

Table 2. Types of Individual Tasks Performed by the Trainees of Educational and Productive Practice in 2013-2021

\begin{tabular}{|c|c|c|c|c|c|c|c|c|c|}
\hline Types of individual tasks & 2013 & 2014 & 2015 & 2016 & 2017 & 2018 & 2019 & 2020 & 2021 \\
\hline Developing and conducting excursions & + & + & + & & + & + & + & + & + \\
\hline Arranging library and archival funds & + & + & + & & & & + & + & + \\
\hline $\begin{array}{l}\text { Development of printed products } \\
\text { (booklets, albums, guides, etc.) }\end{array}$ & + & & & + & + & & & + & + \\
\hline Creating and filling databases & + & & & + & + & & & + & + \\
\hline $\begin{array}{l}\text { Technical work (scanning documents, } \\
\text { typing, etc.) }\end{array}$ & + & + & + & + & & + & & + & + \\
\hline $\begin{array}{l}\text { Work with handwritten and published } \\
\text { historical sources, preparation of } \\
\text { information certificates }\end{array}$ & + & & + & + & & + & & + & + \\
\hline $\begin{array}{l}\text { Preparation of exhibitions and online } \\
\text { exhibitions }\end{array}$ & & & + & + & + & + & + & + & + \\
\hline Necropolis research & & + & + & + & & & + & & \\
\hline $\begin{array}{l}\text { Survey and description of historic } \\
\text { buildings and monuments }\end{array}$ & & & + & & & & + & + & + \\
\hline Shooting videos on local history & & & & & & & + & & + \\
\hline Ethnographic and folklore research & & & & & & & & + & + \\
\hline
\end{tabular}

The head of the practice checks the reports and the level of students' mastery of theoretical material and practical skills, and grades them .The student's performance is monitored on a 100-point scale and translated into an 
assessment on the ECST scale. The overall grade consists of three elements:

- work on theoretical and practical-cognitive classes - 30 points;

- $\quad$ individual project -40 points;

- preparation of reporting documentation and defense of the practice report - 30 points.

After the practice, we conduct a final conference attended by the students, heads of the practice from the department, practice base, faculty. The trainees report about the individual tasks performed, features of working with specific sources or museum, library, archival funds, review the objects of the visited tour. Finally, we sum up the results of the summer educational and productive local history practice.

After passing the local history educational and productive practice, students have the opportunity to continue their local history research and present it to the general public. First of all, it takes place within the framework of the International Conference of Young Scientists, held annually in December at the School of History ofV.N.karazin KhNU.

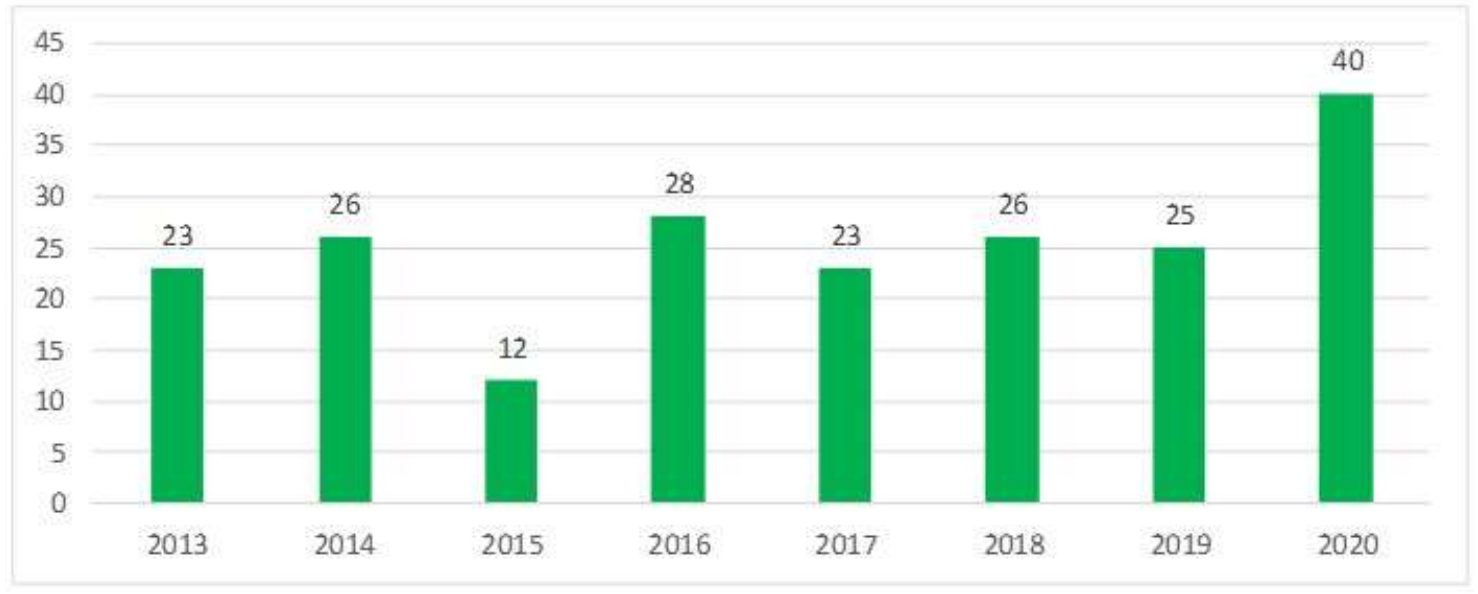

Figure 4. Participation of Students of the School of History, V. N. Karazin KhNU in the International Local History Conference of Young Scientists (2013-2020)

In 2013, 23 students of the School of History, V.N. Karazin KhNU made reports at the sections of the conference. In 2014 there were 26 of them, in $2015-12$, in $2016-28$, in $2017-23$, in $2018-26$, in $2019-25$, in $2020-40$ (see Figure 4).

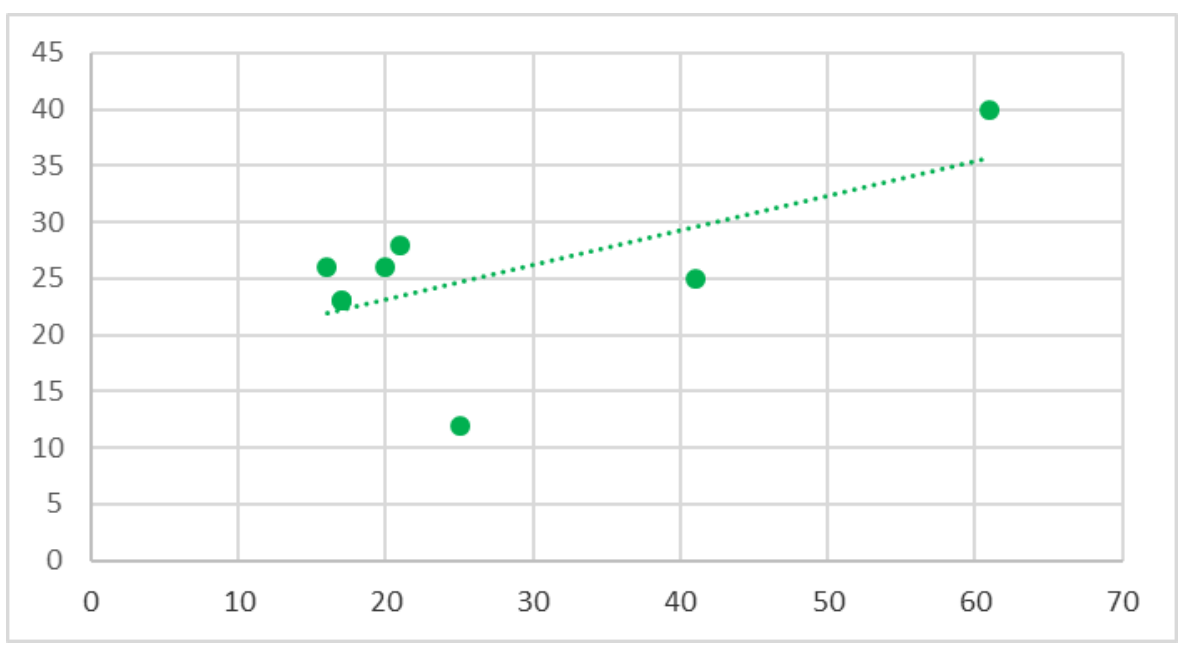

Figure 5. Correlation between the Participation of Students of the School of History in Local History Educational and Productive Practice and in the International Local History Conference of Young Scientists (2013-2020) 
A correlation-regression analysis has showed that there is a direct relationship between the number of participants in the summer local history educational and productive practice and the number of students of the School of History, V. N. Karazin KhNU who made reports at the December International Local History Conference of Young Scientists. Pearson's correlation coefficient between these parameters rxy $=0.633$ (the strength of the correlation of the noticeable level on the Chaddock scale), the value of $t$ of the Student's criterion $\operatorname{tr}=2.003$ at the significance level $\alpha$ $=0.1$ (a trend towards statistical significance) (see Figure 5).

\section{Discussion}

Local history educational and productive practice, which was initiated at V. N. Karazin KhNU in 2013 as part of an all-Ukrainian experiment (Reient, 2021), quickly showed its importance in the system of bachelor-historians' education. Eight years later, it has transformed from a variable component in the educational process into its mandatory element (Vovk \& Kudelko, 2020).

Field classes, excursions and expeditions became an important part of the practice. Such forms of educational activity not only expand the range of professional knowledge and skills of the future historian, but also increase general erudition of students, expanding their horizons (Fedorchenko et al., 2021). We formed the geography of the trips in such a way as to cover the most interesting and attractive sights, significant cultural, educational and research institutions. We take into account not only the administrative boundaries of modern Kharkiv region, but also the borders of Slobozhanshchyna - historical and ethnographic region of Ukraine, covering the territory of the present Kharkiv, eastern Sumy, northern parts of Donetsk and Luhansk regions of Ukraine. Excursions and expeditions allowed trainees to get acquainted with the history, culture, nature of the region where they live and study, as well as to explore neighboring areas and historical and ethnographic regions of Ukraine (Reient, 2021).

Fourteen trips were made in seven years. During that time, students visited 7 local history museums, 10 historical museums and reserves, 4 art museums and galleries, 3 industrial and departmental museums (see Table 1). As international experience shows, the partnership between universities and museums offers great prospects for students to understand and master theories of development and learning (Clark et al., 2016), invaluable for future teachers. It is also worth noting that our graduates work in most of the visited museums and galleries. According to the authors, this is an additional factor in the professional self-determination of trainees.

Due to the integrated nature of local history as a discipline, two national nature parks were additionally included in the sightseeing tour (see Table 1). This allowed us to make field trips an interdisciplinary subject, combining knowledge of historical processes and biological, geographical and geological systems.

As a result, this approach has contributed to a deeper involvement of students in research and raising their awareness not only in the humanities but also in science (Bowcutt \& Caulkins, 2020).

In 2020, when the coronary crisis reached Europe and, in particular, Ukraine, educational institutions switched to remote work. Quarantine conditions have significantly affected the entire educational process and forced the teachers to look for new forms and methods of working with students, ensuring the safety of all participants in the educational process and fully implementing all curricula (Sushko \& Pronchev, 2021).

Leaders of local history educational and productive practice promptly developed a set of training and methodological tools that made it possible to effectively conduct it in a distance format. In particular, as part of consolidating theoretical knowledge, students were offered texts of lectures in a distance course on the Moodle platform, participation in a colloquium and essay writing. It is important to note that many students had to turn to local history museums and specialized departments of local libraries to prepare essays. Some of the trainees noted that by working on this task, they visited these cultural institutions in their hometowns or villages for the first time in their lives. As a result, they were able to deepen their knowledge of their "small homeland", despite the fact that they had been familiar with its history since childhood.

The defining feature of a local history educational and productive practice is its focus on doing real creative or research projects. A wide range of topics and problems were raised for the preparation of such projects (see Table 2) due to the need in comprehensive training of future professionals in accordance with the standards of the specialty. In particular, the educational-professional training program in the specialty "History and Archeology" of the first (bachelor's) level of education at V. N. Karazin KhNU provides that the graduate will have employment prospects as a historian and consultant on history, archivist, expert in museum acquisition and exhibition funds, custodian of exhibits, custodian of funds, archeographer, archaeologist, ethnologist, guide, teacher of secondary school. Based on the history of the region where the student lives and studies, it is possible to fully develop skills and abilities 
associated with future qualified activities in the above professions. The local history factor is especially important in the system of future teacher training due to the trend towards humanization and regionalization of education (Bahchieva, 2018).

Thus, in 2013-2019, most students developed excursion routes and improved guide skills in their projects. This can be explained by the demand for this profession in the labor market. Among such projects it is worth mentioning the routes "Greek Kharkiv", "Kharkiv Cinematic", "Kharkiv in the Life of the Outstanding Local Historian Dmytro Bagaliy", and others. Moreover, some students worked as guides during the field trips mentioned above.

Another popular activity of trainees was exhibition activities. The employees of museums, archives, scientific libraries, where many graduates of the School of History work after graduation, need these relevant skills. The trainees were asked to develop the theme and concept of the upcoming exhibition, get the appropriate visual materials and prepare signatures for them.

For example, in 2015, we launched the collection formation "Kharkiv University in the Mirror of Philately" with the participation of students. Its materials have been repeatedly displayed at the university and abroad. After launching the official website of the Academician P. T. Tronko Center for Area Studies in 2015, the trainees prepared online exhibitions and projects. Among them are "Karazin University on the map of Kharkiv", "Gold of Karazin University", "Student internships at Kharkiv University: a historical excursion", "Paintings as windows into the past: to the 75th anniversary of Ukraine's liberation from Nazism", etc. This form of work corresponds to modern trends in the development of exhibition activities, because digital technologies are actively used in museum sphere all around the world, in particular for creating online exhibitions (Biedermann, 2017).

Organization of library and archival funds both at Academician P. T. Tronko Center for Area Studies, and in partner organizations (V. G. Korolenko Kharkiv State Scientific Library, State Archives of Kharkiv region, etc., - were among the tasks performed by trainees. Some students managed to make real discoveries. For example, in 2014, while studying the manuscripts of the Central Scientific Library of V. N. Karazin Kharkiv National University, they found a previously unknown letter from the university founder Vasyl' Karazin (1773-1842) to the then rector Vasyl Komlyshynsky (1785-1841), dated 1837.

In part, this area of activity is related to another one, which combines the work of trainees in digitizing historical sources and translating their texts into computer format. In particular, archival documents of the 18th - 19th centuries related to the ancient Balkan family of Karazins, whose representatives left a noticeable mark in the history and culture of Ukraine, were processed in this way. It is assumed that the materials prepared by the trainees will be included in the collection of epistolary heritage of Vasyl Karazin (the book should be published in 2023 to the 250th anniversary of the scientist's birth). Recent research shows that working with historical sources (including digitized ones) is useful in teaching local history (Guerrero Elecalde, 2020).

Another common form of trainees' work was the preparation of research and information related to little-studied aspects of the history of Kharkiv and Sloboda Ukraine. In particular, they conducted original explorations, dedicated to kobzars, lyre players and bandura players of Sloboda Ukraine of the 18th - 19th centuries; genealogy of the Prime Minister of France Pierre Bérégovoy, whose ancestors came from Slobozhanshchyna; developed a project of information improvement of Kharkiv by creating a network of information boards near the most outstanding monuments, etc.

An important area of the trainees' research was necropolis, closely related to monuments, biography, genealogy and other special historical subjects. Students inspected the city cemeteries, took photos of typical and original samples of tombstones, formed a collection of epitaphs. These investigations are valuable for study of regional and national identities (Vajta, 2021). Burial places of graduates and teachers of Kharkiv University were cataloged, their graves were photographed in order to assess the state of preservation and the need for reconstruction work. Search work has revealed previously unknown or forgotten sights. For example, in 2014, the trainees found a forgotten mass grave of soldiers of the German army during the First World War in Kharkiv. The find was reported to the relevant departments of Kharkiv City Council and the Consulate General of Germany in Ukraine. Based on the results of the survey, the trainees prepared a report, which was delivered during the International Scientific Conference dedicated to the 100th anniversary of the beginning of the First World War.

During the local history practice, students also surveyed and described historic buildings and sites. For example, in 2016, they surveyed the old buildings of Kharkiv University in order to identify artifacts of university history of the 19th - first half of the 20th century. In 2019, they described and cataloged a complex of buildings and structures in Kharkiv, related to the life and work of the graduates and staff of Kharkiv University. This task, like some others, 
was performed within the framework of the V. N. Karazin KhNU Development Strategy for 2019-2025 (Pavlova, 2020).

The students actively participated in creation and filling of databases. In particular, they collected and systematized information about monuments and memorial plaques of Kharkiv, memorial auditoriums of Kharkiv University. They took photos of the relevant "places of memory", collected information about their creation, studied the current state of preservation. Modern publications confirm that the involvement of students in archiving historical documents and filling digital data banks, on the one hand, allows to solve specific problems of preservation and promotion of historical and cultural heritage in museums, and on the other - makes specialized curricula more interesting for higher education. (Schuster \& Grainger, 2021).

During the local history practice, students had the opportunity to improve their skills in printing design, developing samples of booklets, albums, guides to local history. For example, the booklets to the 50th anniversary of Kharkiv University's relocation to the modern Main Building (2013) and to the 250th anniversary of the birth of a prominent historian, Honorary Doctor of Kharkiv University Mykola Karamzin (2016), a souvenir album "Views from the windows of Kharkiv University" (2017) and others, are worth mentioning. (Vovk \& Kudelko, 2020).

In 2020 and 2021, when local history practice took place remotely, the geographical dispersion of participants (see Figure 3) led to a decrease in the number of collective and a growing number of individual projects. In some cases, the trainees performed one common task, but worked on their area of interest individually. This concerned, for example, the formation of a photo database of the streets of Kharkiv, named after outstanding graduates and teachers of Kharkiv University; filling the database of the international research project "Practices of the self-representation of multinational cities in the industrial and post-industrial era", etc. (Posokhov \& Rachkov, 2020).

In 2020-2021, the range of individual tasks that trainees worked on expanded, primarily due to ethnological and folklore topics (see Table 2). Visiting their native village or settlement, they had the opportunity to explore samples of local intangible cultural heritage (embroidery ornaments, legends and traditions, etc.). Scientific and methodological support of such activities became possible due to the activities of the Department of Ethnography in the structure of Academician P. T. Tronko Center for Area Studies V. N. Karazin KhNU (Shport, 2020).

It is worth noting that a number of tasks, performed by trainees, were later represented in other regional and international projects and programs. For example, the work "Legends of Khorosheve village" (2020) was presented at Kharkiv regional youth competition "Legends of the native land", where it won a prize. The project "Trails of the Kosach family in Volyn" (2021) was completed to the 150th anniversary of the birth of Lesya Ukrainka.Her anniversary was included in the List of significant dates of UNESCO. The project of the excursion-tourist route through the town of Chasiv Yar, Donetsk region (2021) was presented during the travel idea "My tourist community-Myropolis", which is part of the UN program for peace restoration and development.

The International Conference of Young Scientists became an important platform for presentation of trainees' own local history research. It has been held at the School of History, V. N. Karazin KhNU since 1983 and is the oldest youth forum in Ukraine, where the we discuss problems of historical regionalism. Nowadays, the conference has become a prestigious scientific event, which in different years was attended by representatives of all regions of Ukraine, as well as delegates from Belarus, Bulgaria, India, Poland, Uzbekistan, the Czech Republic and other countries. Many former participants of the International Conference of Young Scientists, who spoke at its sections during the 1980s and 2000s, have already defended their $\mathrm{PhD}$ and doctoral dissertations, hold senior positions in the higher education system and held important positions in specialized departments, public authorities and local governments, have become recognized experts in the field of history, local history, monument studies. For many of them, speaking at this conference was the first opportunity to try their hand at science (Mankovska, 2015).

The study of the ratio of students' involvement in local history educational and productive practice of the School of History, V. N. Karazin KhNU and the International local history conference of young scientists shows that there is a moderate correlation with a trend towards statistical significance between these indicators (see Figure 5). In other words, the growing number of participants in the local history practice in July-August leads to an increase in the number of students wishing to speak at the International Local History Conference in December of the same year.

Empirical confirmation of this pattern is the observation that after the approval of the mandatory status of the local history practice not only students specializing in the departments with traditionally developed topics of local history (historiography, source studies and archeology; history of Ukraine; history of Eastern Europe), but also representatives of the departments far from the problems of local history (history of the ancient world and the Middle Ages; modern and contemporary history) became participants in the conferences. Some of these students become 
permanent participants of the International Local History Conference.

These facts indicate that participation in the local history educational and productive practice stimulates further research activity of students in the field of historical local studies.

\section{Conclusions}

Thus, local history educational and productive practice is an important component of training a future bachelor of history. This form of work gives students the opportunity to improve their skills in collecting and processing historical sources, to join the description and cataloging of historical and cultural monuments, to create and test creative projects of local history.

By 2019, V. N. Karazin KhNU has developed a set of approaches to local history practice. The system of individual tasks, selected according to the interests and aptitudes of each individual student, in combination with meaningful field trips, made the practice not only useful but also interesting for the participants.

After the outbreak of the COVID-19 pandemic, we had to transfer the local history educational and productive practice to a distance format. Interaction between practice leaders and students took place with the help of modern means of telecommunications. An individual approach to the selection of topics for practical tasks allowed students not only to complete the educational project, but also to significantly expand their knowledge about their homeland. Methodological approaches, developed to ensure distance learning of local history practice, may be useful after returning to the traditional full-time system of education.

The study revealed a statistically significant moderate correlation between the number of students who participated in the local history educational and productive practice, and the number of students of the School of History of V.N. Karazin KhNU - participants of the International Conference of Young Scientists. This confirms that such educational activity as local history educational and productive practice helps increase students' interest in further research in the field of local history.

\section{References}

Anderson, C., \& Day, K. (2005). Purposive Environments: Engaging Students in the Values and Practices of History. Higher education, 49(3), 319-343. https://doi.org/10.1007/s10734-004-6676-y

Bahchieva, O. A. (2018). Integrative Opportunities of Local History within Spiritual and Moral Education of Teacher. International Conference on Research Paradigms Transformation in Social Sciences, 35, 100-106. https://doi.org/10.15405/epsbs.2018.02.12

Biedermann, B. (2017). 'Virtual museums' as Digital Collection Complexes. A museological perspective using the example of Hans-Gross-Kriminalmuseum. Museum Management and Curatorship, 32(3), 281-297. https://doi.org/10.1080/09647775.2017.132291

Bilotserkovets, M., Fomenko, T., Kobzhev, A., Berestok, O., Shcherbyna, Y., Krekoten, O., \& Kurinnyi, A. (2021). Dual Nature of Students' Knowledge Formation in the Pandemic Period: Pedagogical and Psychological Aspects. Revista Romaneasca pentru Educatie Multidimensionala, 13(3), 246-261. https://doi.org/10.18662/rrem/13.3/450

Bowcutt, F., \& Caulkins, T. (2020). Co-teaching Botany and History: An Interdisciplinary Model for a More Inclusive Curriculum. Isis, 111(3), 614-622. https://doi.org/10.1086/711071

Clark, M., Ensminger, D., Incandela, C., \& Moisan H. (2016). Reflections on Museums as Effective Field Sites for Teacher Candidates. Journal of Museum Education, 4, 329-340. https://doi.org/10.1080/10598650.2016.1219127

Coddington, N. E. (2020). "Putting it in Technicolor": The Influence of a Pre-Service Teaching Residency at a Historic Site, Archive, Library, or Museum on In-Service Pedagogical Practices. Journal of Social Studies Research, 44(2), 219-238. https://doi.org/10.1016/j.jssr.2020.01.003

Fadeev, A. (2019). Redesigning Contemporary Learning in Literature, History and Culture Through Online Learning Environments. 15th International Scientific Conference on eLearning and Software for Education, 223-228. https://doi.org/10.12753/2066-026X-19-101

Fedorchenko, V. K., Kutuev, P. V., Fedorchenko, N. V., \& Vasilets, O. I. (2021). Tourism and Education in Formation of the Human Capital Agency. Linguistics and Culture Review, 52(5), 246-258. 
https://doi.org/10.37028/lingcure.v5nS2.1343

Guerrero Elecalde, R. (2020). The Use of Documentary Sources for the Teaching of the Local History of Cordoba, Spain. The Catastro de Ensenada as a Didactic Resource. Magazine of the Faculty of Education of Albacete, 35(2), 55-69. https://doi.org/10.18239/ensayos.v35i2.2334

Homrighausen, J. (2020). Touching Sacred Texts, Touching History: Using Manuscripts to Teach Scribal Practices and Material Scripture in the Biblical Studies Survey Course. Teaching Theology and Religion, 23(4), 276-285. https://doi.org/10.1111/teth.12558

Mankovska, R. (2015). The Statesman, the Scientist, the Citizen. Celebrating the 100th Aniversary of Petro Tronko's Birth in Ukraine. Kraêznavstvo, 3/4, 27-36.

Maughan, H., \& Jane, S. (2020). Making Archives - A Case Study of Creative Collaboration. The Journal of Archives and Records Association, 41(2), 148-169. https://doi.org/10.1080/23257962.2020.1713071

Patterson, T. (2020). Historians, Archivists, and Museum Educators as Teacher Educators: Mentoring Preservice History Teachers at Cultural Institutes. SAGE Journals. Collection, 72(1), 113-125. https://doi.org/10.25384/SAGE.c.5250813.v1

Pavlova, O. (2020). Museum Complex of V. N. Karazin Kharkiv National University in the Cultural and Educational Space. The Ist International scientific and practical conference "Topical Aspects of Modern Science and Practice", September 21-24, 2020, Frankfurt am Main, Germany.

Pavlova, O., \& Kudelko, S. (2015). Museum Studies, History of Art and Monument Studies at the Historical Faculty of V. N. Karazin Kharkiv National University. The Journal of V. N. Karazin Kharkiv National University. Series: History, 50, 145-152.

Posokhov, S. I., \& Rachkov, Y. S. (2020). Searching for the 'Face' of the City (Foreword). The Journal of V. N. Karazin Kharkiv National University. Series: History, 57, 11-12.

Reient, O. (2021). Local Lore in Ukraine: Historical Traditions and Strategy of Development. Kyiv: National Union of Local Historians of Ukraine.

Schuster, K., \& Grainger, J. (2021). Digital Cultural Heritage: Collaborating with Students and Discovering Lost Museums. Education for information, 37(1), 97-111. https://doi.org/10.3233/EFI-190352

Shport, G. M. (2020). Ethnographic Profile Exhibitions as an Important Means of Forming the National Consciousness of Student and Student Youth (On the Materials of the Exhibition "Ukrainian Pysanka: The Sealed Facets of the Spiritual", June 7-26, 2018). Problems of the Museum Educational in Ukraine, 5, 153-160.

Sushko, V. A., \& Pronchev, G. B. (2021). Online Learning in the Context of Pandemic in Russia. Romanian Journal for Multidimensional Education, 13(2), 01-17. https://doi.org/10.18662/rrem/13.2/407

Vajta, V. (2021). Identity beyond death: Messages and meanings in Alsatian cemeteries. Mortality, 26(1), 17-35. https://doi.org/10.1080/13576275.2020.1715360

Varfolomeyev, A., Korzun, D., Ivanovs, A., Soms, H., \& Pashkov, A. (2015a). Smart Space Services as a Teaching Aid in History and Cultural Heritage Studies. 8th International Conference of Education, Research and Innovation, 1373-1380.

Varfolomeyev, A., Korzun, D., Ivanovs, A., Soms, H., \& Petrina, O. (2015b). Smart Space based Recommendation Service for Historical Tourism. Procedia Computer Science, 77, 85-91. https://doi.org/10.1016/j.procs.2015.12.363

Vovk, O., \& Kudelko, S. (2020). Local Lore Practice in Quarantine Regime (Experience, Problems, View in the Future). Problems of Contemporary Education, 11, 70-74.

\section{Copyrights}

Copyright for this article is retained by the author(s), with first publication rights granted to the journal.

This is an open-access article distributed under the terms and conditions of the Creative Commons Attribution license (http://creativecommons.org/licenses/by/4.0/). 